\title{
PLAN ISPITIVANJA MEŠAVINA ZA GRADNJU ZEMLJOM
}

Ivan Hegediš ${ }^{1}$

Čeh Arpad $^{2}$

Golub Karaman ${ }^{3}$

Edita Tenji ${ }^{4}$

УДК: 691.4

DOI:10.14415/konferencijaGFS 2015.096

Rezime: Tradicionalni načini gradnje predstavljaju iskustvo izgrađeno kroz dugu istoriju graditeljstva. Današnja saznanja u tehnici i tehnologiji omogućuju da se tradicionalna iskustva ispitaju $u$ unaprede kako bi našla primenu u savremenim uslovima. Građenje zemljom je široko rasprostranjeno i predstavlja veliki potencijal za savremnu primenu.

Ispitivanje mešavina zemlje sa drugim prirodnim materijalima zasnovano na tradicionalnim iskustvima treba da pokaže kako se može preciznije pripravljati $i$ ugrađivati ova vrsta materijala uz manji utrošak energije i rada, kako se može graditi zdrava i udobna kuća sa visokom energetskom održivosti.

Ključne reči: zemlja, mešavina, naboj

\section{UVOD}

Kroz dugu istoriju ljudske civilizacije razvili su se raznoliki načini gradnje korišćenjem materijala nađenih u neposrednoj okolini gradnje. Oni su uz minimalnu obradu služili da se oblikuju prostori u kojima ljudi žive i rade. Danas ovakve načine gradnje nazivamo jednim imenom - tradicionalna gradnja.

Međju takvim materijalima zemlja je najviše rasprostranjena. Još i danas veliki deo svetske populacije živi u kućama gradjenim zemljom na različite načine: nabijanjem, zidanjem, malterisanjem...

Kroz dugu primenu došlo se do spoznaje da se dodavanjem nekih organskih materija poboljšavaju osobine zemlje (sir kod Kineskog zida, balega kod berberskih kuća ili životinjska krv u našim krajevima) kao osnovne mešavine i biljnih vlakana kao armature (slama, trska, kudelja i sl.) kao konačne mešavine za ugradnju.

\footnotetext{
${ }^{1}$ Dr Ivan Hegediš, dipl. inž. arh., Univerzitet u Novom Sadu, Građevinski fakultet Subotica, Kozaračka 2a, Subotica, Srbija, tel: 024554 300, e - mail: hege@tippnet.rs

${ }^{2}$ Arpad Čeh, dipl. inž. građ., Univerzitet u Novom Sadu, Građevinski fakultet Subotica, Kozaračka 2a, Subotica, Srbija, tel: 024554 300, e - mail: ceh@gf.uns.ac.rs

${ }^{3}$ Golub Karaman, dipl. inž. građ., Univerzitet u Novom Sadu, Građevinski fakultet Subotica, Kozaračka 2a, Subotica, Srbija, tel: 024554 300, e - mail: golub@gf.uns.ac.rs

${ }^{4}$ Edita Tenji, Univerzitet u Novom Sadu, Tehnološki fakulte,Novi Sad, Srbija, edit@tippnet.rs
} 


\section{$41^{\text {th }}$ ANNIVERSARY FACULTY OF CIVIL ENGINEERING SUBOTICA}

International conference

Contemporary achievements in civil engineering 24. April 2015. Subotica, SERBIA

Povećani zahtevi za smanjenje utroška energije u proizvodnji i ugradnji materijala i upotrebi objekata usmerili su pažnju na tradicionalne materijale koji svojim osobinama mogu da odgovore na pravi način.

Potrebno je preciznije utvrditi koji i kakvi materijali i u kojem odnosu se mogu mešati sa zemljom da bi se dobile zadovoljavajuće karakteristike za savremenu gradnju. Zato je pokrenuto ispitivanje mešavina za gradnju zemljom u laboratoriji Građevinskog fakulteta Subotica uz učešće studenata u okviru nastave iz predmeta Tradicionalni materijali. Ispitivanje se provodi u nekoliko faza (prikazano na slici) sa zemljom poznatog sastava (iskop Potisje Kanjiža).

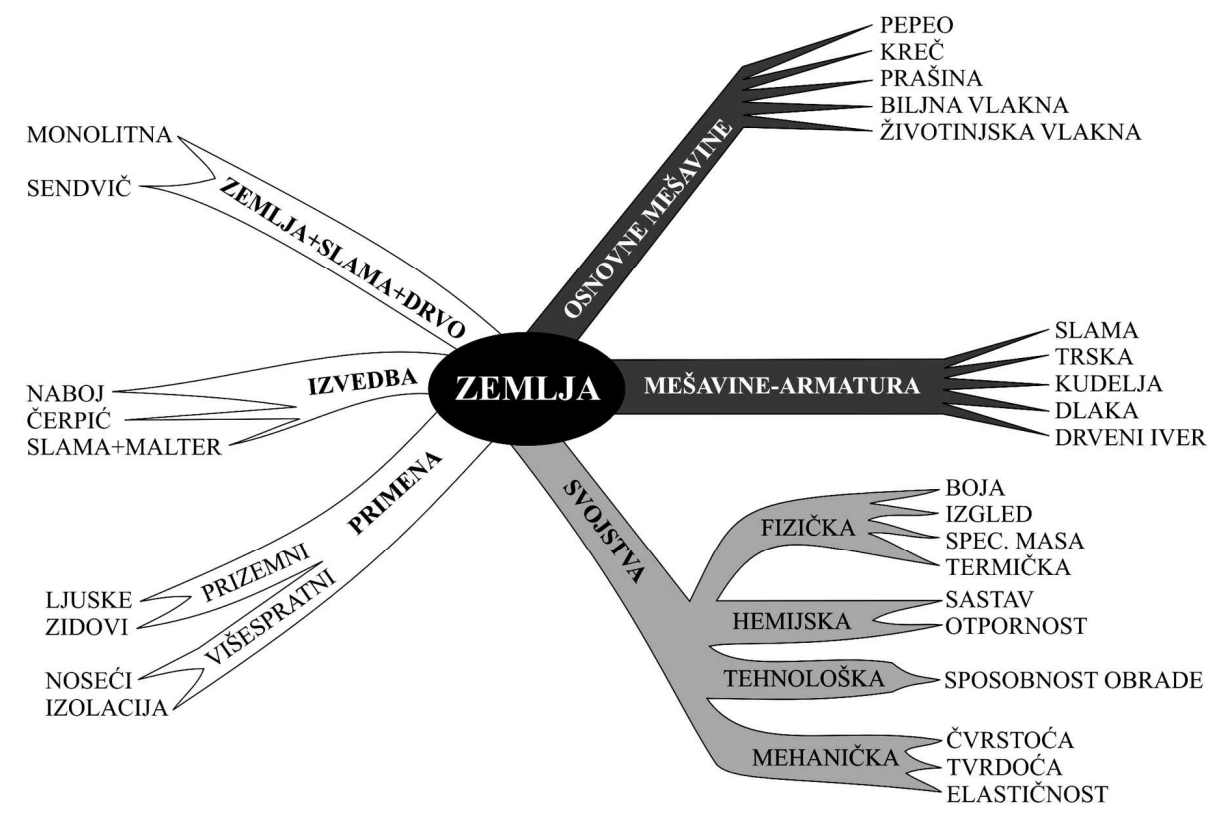

\section{OSNOVNE ME ̌̌AVINE}

Ispitivanje se vrši izradom epruveta $4 \times 4 \times 16 \mathrm{~cm}$ nabijanjem u čeličnim šablonima a zatim sušenjem 28 dana po standardnoj proceduri. Prvo se izrađuju epruvete od čiste zemlje kao repernog uzorka. Zatim se rade mešavine dodajući različite kolićine čestica drvnog pepela, kreča, biljnih vlakana, sitne životinjske dlake i prašine kao ostatka rušenja starih objekata. Cilj je da se utvrdi koliko dodati materijal popravlja karakteristike zemlje. Naime, postoji više uzroka koji smanjuju mehanička svojstva naboja. Najznačajniji je posledica osobine gline da vezuje veliku količinu vode koja sušenjem isparava i dovodi do pojave pukotina u strukturi naboja koje mu umanjuju mehanička svojstva. Drugi faktor koji utiče na osobine naboja jeste hemijski i fizički sastav zemlje koji se 
Међународна конференција

Савремена достигнућа у грађевинарству 24. април 2015. Суботица, СРБИЈА

iskustveno poboljšava dodavanjem već navedenih materijala ili, kako to danas preporučuju, manjeg procenta portland cementa (3-5\%).

Kako je osnovni princip u ovom ispitivanju primena prirodnih materijala sa malim utroškom energije u pripremi, primena cementa je odbačena. Jedino je zadržan kreč koji predstavlja najviše energetski zahtevan materijal u osnovnim mešavinama i to u malom procentu. U literaturi postoje objavljeni rezultati ispitivanja zemlje sa dodavanjem cementa koji će služiti za upoređivanje.

Ispitivanje osnovnih mešavina izvršeno je tokom prolećnog i zimskog semestra 2104. godine. Izvršena su merenja mehaničkih osobina, vodootpornosti i zamrzavanja. U toku su pripreme izveštaja i objavljivanje rezultata o ovim ispitivanjima.

\section{MEŠAVINE - ARMATURA}

Druga faza ispitivanja (u toku prolećnog semestra 2015.) sastoji se u dodavanju različitih prirodnih vlakana kao armature u osnovne mešavine čime se dobija konačni zemljani naboj kojim se vrši gradnja. Kao armatura služe različita prirodna vlakna: trska, slama, životinjska dlaka, kudeljna vlakna i sl. Ovako pripremljeni uzorci ispitaće se na isti način kao osnovne mešavine.

Dobijeni rezultati pokazaće kako se može pripravljati odgovarajuća mešavina za naboj, ali može poslužiti kao direktiva za izradu čerpića i maltera.

\section{IZVEDBA}

Naredna faza predstavlja ispitivanje izvedenih konstruktivnih sklopova koje će se vršiti u laboratorijskim uslovima $i$ na terenu. Laboratorijska ispitivanja će se izvoditi na zidovima izvedenim u stvarnoj veličini gde se mogu ispitati mehanička i termička svojstva i pratiti spoljni uticaji u realnim uslovima (kiša, sneg, sunce, vetar).

Planira se izvođenje zidova od naboja, čerpića i slame.

Terenska ispitivanja mogu se izvoditi dvojako i predstavljaju mogućnost realizacije kao posebnih programa. Prvi je ispitivanje postojećih objekata građenih od zemlje gde se može pratiti niz faktora koji utiču na objekte tokom njihove upotrebe. Drugi je primena rezultata laboratorijskih ispitivanja na objektima koji se grade kao novi.

\section{ZEMLJA, SLAMA, DRVO}

Prvi objekat na kojem će se primeniti rezultati ovih ispitivanja biće na objektu u Malom Pesku čija gradnja je u toku. Stambeni objekat koji se gradi biće izveden kao bondručna drvena konstrukcija sa zidovima građenih slamom malterisanim blatnim malterom.

Ova izvedba pruža mogućnost da se, u dogovoru sa investitorom, primene odgovarajuće mešavine koje se kasnije ispituju i proveravaju njihova svojstva kao i uticaj na kvalitet objekta tokom gradnje i u korišćenju. 


\section{PRIMENA}

Po izvođenju i ispitivanju konstruktivnih sklopova u trećoj fazi mogu se dobijeni rezultati primeniti na projekte različitih tipova objekata. Realizacija je moguća u okviru nastave na predmetima Projektovanje porodične kuće, Projektovanje višeporodičnog stanovanja, Projektovanje specijalnog stanovanja i kroz diplomske radove studenata. Isto tako se predviđa mogućnost pokretanja projekata sa lokalnom samoupravom u okviru prekogranične saradnje kako bi se podstakla primena svih vidova gradnje zemljom.

\section{ZAKLJUČAK}

Ispitivanje mešavina zemlje za gradnju pokazuje da je potrebno kao pokretač za gradnju kuća koje će biti ekonomičnije, energetski održive i zdravije zbog svojstava prirodnih materijala. Primena tradicionalnih graditeljskih iskustava $\mathrm{u}$ savremenom graditeljstvu može da pokrene preduzetništvo $u$ proizvodnji široke palete materijala, poluprefabrikovanih i prefabrikovanaih elemenata za montažnu gradnju, kao i efikasnu građevinsku operativu za sve vidove gradnje zemljom. Izostanak velike mehanizacije i niske potrebe za energijom pokazuju da je uz mala ulaganja privređivanje $u$ ovom području dostupno širokom broju ljudi. Na taj način može se ostvariti veće zapošljavanje i graditi ekonomične i zdrave kuće.

\section{ANALISYS OF EARTH CONSTRUCTION MATERIALS}

Summary: Traditional ways of construction represent the experience gathered in a long history of civil engineering. The present knowledge in engineering and technology makes it possible, by observing the traditional experiences to improve into practical applications in modern conditions. Earth construction is widespread and constitutes a great potential for contemporary application.

Analyzing the mixtures of earth with other natural materials based on traditional experience should demonstrate how they can be improved and built in using less energy and more effective, in order to build a healthy and comfortable house with high energy sustainability.

Keywords: earth, mixtures, rammed earth 